\title{
Nina Rodrigues e a loucura das multidões
}

\author{
Nina Rodrigues and the madness of crowds
}

\author{
FILIPE PINTO MONTEIRO
}

Casa de Oswaldo Cruz | COC-FIOCRUZ

\begin{abstract}
RESUMO Este texto tem por meta analisar um conjunto documental pouco explorado referente às pesquisas do médico Raimundo Nina Rodrigues sobre fenômenos coletivos registrados entre o final do século XIX e inicio do XX. Pretendemos dar ênfase a algumas reflexões do referido autor e, especialmente, ao diálogo que ele estabeleceu com profissionais estrangeiros do campo da sociologia, da antropologia e da saúde mental. O esforço intelectual de Nina é como um testemunho do nascimento de um campo de estudos cujas primeiras linhas estavam sendo traçadas no Brasil: a psicologia das massas ou loucura das multidões. Nina resgata uma rica tradição de estudos para abordar, à sua maneira, casos de epidemias coletivas e religiosas no Brasil, vinculadas à população negra e mestiça.
\end{abstract}

Palavras-chave Nina Rodrigues - multidões - loucura - religião - miscigenação.

\begin{abstract}
This text is aimed to analyse an underexplored set of documents related to the research referring to the physician Raimundo Nina Rodrigues on collective phenomena recorded between the late nineteenth and early twentieth centuries. We intend to emphasize some reflections of that author and especially the dialogue which he established with foreign professionals in the field of sociology, anthropology and mental health. Nina's intellectual effort is like a witness of the birth of a field of study whose first lines were being drawn in Brazil: crowd psychology or the madness of crowds. Nina rescues a rich tradition of studies to address, in its way, cases of collective and religious epidemics in Brazil, linked to the black and miscegenated population.
\end{abstract}

Keywords Nina Rodrigues - crowds - madness - religion - miscegenation.

\section{Introdução}

É possível afirmar que Raimundo Nina Rodrigues foi um dos primeiros intelectuais brasileiros a, sistematicamente, teorizar e formular hipóteses sobre o campo da chamada Psicologia das Multidões. Esse aspecto foi apontado, pela primeira vez pelo médico Arthur de Araújo Pereira Ramos (1903-1949) no prefácio do livro As collectividades anormais, coletânea de textos de Nina Rodrigues, reunida pelo primeiro em 1939:

Nina Rodrigues, já apontado como o iniciador dos estudos de etnografia e psicologia social do negro, no Brasil, já conhecido como estudioso de nossos problemas de raça e de cultura, aclamado como uma das autoridades em criminologia e ciência penal.... talvez não fosse lembrado, pela nossa pobre ciência nacional, tão esquecida dos precursores, como um dos pioneiros do movimento da psicologia coletiva.

No entanto o seu nome fora apontado pelos estudiosos europeus, como um dos fundadores da psicologia das multidões, um dos criadores da psicologia gregária, normal e patológica, ao lado dos Rossi, dos Si- 
ghele, dos Tarde, dos Le Bon, dos A. Marie... Na história das epidemias religiosas, o seu nome é citação obrigatória, pois foi ele um dos primeiros a realizar observações e comentários científicos sobre fenômenos brasileiros de psicopatologia gregária, trazendo assim contribuições fundamentais à nova ciência em elaboração pelos teóricos europeus. ${ }^{1}$

Ramos esforçou-se em seu tempo para mudar um cenário de desvalorização da obra de Nina Rodrigues sobre as multidões. A tentativa, entretanto, não prosperou. Ao longo das décadas seguintes, os trabalhos sobre a produção científica de Nina permaneceram focados na sua valiosa contribuição para os campos antropológico-criminais, médico-legais e, sobretudo, para a "etnografia" e "economia étnica" da população afro-brasileira. ${ }^{2}$ Mariza Corrêa, em artigo publicado sobre Nina, informa que infelizmente, boa parte de seus trabalhos que não encaixavam nesses temas "permanece inédita e este texto é assim também uma sugestão para que os interessados nos assuntos tratados por ele naqueles trabalhos os leiam". ${ }^{3}$

Em outra resenha bibliográfica, Corrêa denuncia o que classifica, oportunamente, de "um escândalo epistemológico de grandes proporções na história das ciências sociais no Brasil". ${ }^{4}$ Ela refere-se ao quase completo desconhecimento de alguns trabalhos de Nina - artigos publicados apenas em francês e outros tantos esquecidos nas gazetas e foIhetins médicos -, além de importantes livros, que há muito não recebem novas e atualizadas edições, nem mesmo reimpressões. Diz a pesquisadora:

(...) um dos autores obrigatoriamente citado quando se trata de analisar as chamadas relações afro-brasileiras no país, é também o estranho caso de um pensador famoso cuja obra é praticamente desconhecida de grande parte dos pesquisadores brasileiros, e quase inacessível a eles, não só aos que se interessam por essas relações como também àqueles que se interessam pela história do sanitarismo, da saúde pública, dos códigos civil e penal, ou pela história da loucura no nosso país. ${ }^{5}$

A psiquiatra Ana Maria Galdini Raimundo Oda foi uma exceção a essa regra, pois examinou alguns escritos do pesquisador maranhense relacionados à também denominada Psicologia Gregária. Ao analisar o estudo de Nina sobre uma epidemia histérica que ocorreu em Salvador, em 1882, Oda ressalta que, diferentemente da maioria dos médicos no Brasil, ele deu uma contribuição original ao caso. Sua preocupação estava em entender como manifestações histéricas individuais teriam se propagado, "que condições haviam permitido que se tornassem coletivas ou epidêmicas". ${ }^{6}$

Recentemente, em um texto sobre religião e saúde mental, o médico Paulo Delgalarrondo, autor interessado na história da psiquiatria no Brasil, afirmou que Nina foi possivelmente o primeiro a estudar as epidemias de loucura coletiva no país - uma pressuposição da qual compartilhamos a partir das fontes analisadas. Para Delgalarrondo, os trabalhos de Nina que abordavam fenômenos histéricos e neurastênicos de grande proporção expressam uma "percepção aguda de como crenças poderosas podem atuar sobre um terreno fértil de populações vulneráveis ao contágio imitativo". ${ }^{7}$

As populações propensas às epidemias de loucura usualmente são caracterizadas, por Nina Rodrigues, como miscigenadas, o que coloca a "questão racial" no epicentro de seus estudos. Porém, como bem lembra Corrêa, apesar de o debate sobre relações raciais ser também o foco das análises feitas sobre o legista maranhense até muito recentemente, "já é boa hora tanto de enfocarmos outros ângulos de seu trabalho como de procurar reler suas observações sobre essa questão". ${ }^{8}$

A mistura de raças nunca foi o principal e único tema na produção acadêmica de Nina. Aluno da Faculdade de Medicina da Bahia desde 1882, ele viria a completar o sexto ano do curso em 1887 na Faculdade de Medicina do Rio de Janeiro, com a defesa da tese de doutoramento Das amyotrophias de origem periférica. Manteve-se então preocupado com questões relacionadas à Saúde Pública, de modo geral, como é possível depreender, por exemplo, de sua ativa participação em comissões e grupos de planejamento institucional na Bahia e em âmbito federal. ${ }^{9}$

Ocupado com a estruturação de um serviço sanitário adequado em Salvador, Nina versou também sobre temas ligados à nutrição, à dermatologia e à higiene do meio urbano e rural. Atentou para o tratamento dos alienados nos asilos 
de Salvador e São Luiz; para os equívocos, que em sua opinião, impugnavam o Código Penal de 1894 e o Código Civil de 1901; para as questões ligadas à liberdade profissional; para os serviços de prevenção às doenças infectocontagiosas; para 0 ensino de Medicina Legal no Brasil, entre outros assuntos. ${ }^{10}$

A partir da projeção que ganhou com estes estudos Nina chegou a ser nomeado como representante do Brasil no IV Congresso Internacional de Assistência Pública e Privada que se reuniria em Milão em 1906, ano de sua morte. ${ }^{11}$ Argumenta Corrêa, seguindo uma trilha aberta por Edison Carneiro, que o Nina especialista na questão racial nasceu muitos anos depois, graças à publicação "seletiva" de seus estudos, por "autoproclamados" discípulos, particularmente Arthur Ramos, este sim, interessado no assunto. ${ }^{12}$

Tendo por base esses apontamentos e inspirados em autores como Oda e Delgalarrondo, nossa intenção é de alguma maneira, seguir as sugestões de Mariza Corrêa, e reconstituir o discurso de Nina, no caso, sobre enfermidades mentais contagiosas. Acreditamos que assim será possível não apenas recompor o extenso quadro analítico deste autor, exposto, sobretudo, no compêndio As collectividades anormais.

\section{A Psicologia das Multidões: Tarde e Sighele}

A Psicologia Coletiva surgiu na segunda metade do século XIX, momento em que se esboçava, em linhas gerais, um ramo do conhecimento mais amplo que viria a se chamar Psicologia Social. Não há consenso entre os estudiosos do tema sobre o momento em que esta última se estruturou enquanto disciplina cientifica, mas sabe-se que foi em algum ponto da primeira metade do século seguinte. 0 estudo das coletividades, por sua vez, emergiu paralelo a outras ciências afins, em especial a Sociologia. Suas vertentes francesa e italiana, muito próximas uma da outra, produziram trabalhos importantes sobre as multidões e Nina Rodrigues tornou-se leitor assíduo de seus autores de maior renome. ${ }^{13}$

Nina foi um profissional que circulou pelos principais centros acadêmicos de seu tempo, como as Faculdades de Medicina do Rio e da Bahia, e também foi correspondente de importantes entidades científicas nos Estados Unidos, como A Medico-legal Society of New York, e na Europa, especialmente na França, através da Société Médico-Psychologique de Paris. ${ }^{14}$ Tal caminho possibilitou que adquirisse algumas obras de difícil acesso citadas em seus trabalhos. Tendo acumulado experiência no campo da psiquiatria clínica e medicina-legal, comentou e criticou diversos autores. Entre eles sobressaem-se os franceses Gabriel Tarde (1843-1904) e Scipio Sighele (1868-1913).

Tarde pode ser apontado como um dos marcos da sociologia francesa do século XIX. Após sua morte, porém, seu legado permaneceu à sombra de Émile Durkheim (1858-1917) e apenas muito recentemente, nas quatro últimas décadas do século XX, surgiu um renovado interesse em seus estudos. Segundo interpretações correntes, Tarde elabora uma espécie de microssociologia da existência de crenças e desejos, procurando entender como se dá a sua perpetuação e/ou desaparecimento no meio social. ${ }^{15}$

Tal explicação ocorre, grosso modo, pela analogia que é estabelecida entre a repetição de fenômenos em áreas como, por exemplo, a física e suas ondas vibratórias continuadas, com aqueles da transformação social que, por sua vez, funcionariam pela sugestão, imitação e repetição. ${ }^{16}$ Essa tendência, em última instância, aplicaria o termo "social" a qualquer tipo de associação. Segundo o sociólogo Eduardo Viana Vargas, indivíduos e sociedades, para Tarde, são "como células e átomos, são todos compostos e, como tais, imediatamente relacionais". ${ }^{17}$

Já Sighele, jurista de formação, foi um dos nomes fortes da escola de criminologia italiana ao lado de Cesare Lombroso (1835-1909), Enrico Ferri (1856-1929), Raffaele Garofalo (1851-1934) e Pasquale Rossi (1867-1905). De certa forma, este autor tentou aplicar à dimensão da coletividade, ideias que Lombroso havia pensado para 0 individuo delinquente..$^{18} 0$ homem, vítima de seus próprios instintos, seria, também, sensível às influências externas, igualmente negativas. Sugestionável, a multidão atuaria em conformidade com um modelo pessimista aplicado ao desempenho individual. 
Em Sighele a coletividade é como um agregado heterogêneo, composto por indivíduos de idade, sexo, classe e condições sociais diferentes. 0 que os unem é a crença comum em uma ou mais ideias que tiveram origem e foram exaustivamente repetidas por um individuo agregador capaz de constranger os demais a segui-lo em um empreendimento comum. Ao receber estímulos de um agente externo e manifestá-los conforme as impressões adquiridas, os indivíduos apresentam uma condição que o antropólogo Giuseppe Sergi (1841-1936) ${ }^{19}$ chamou de receptividade reflexiva, considerada por Sighele uma lei fundamental da psique humana, exacerbada nas multidões.

Sergi e Sighele seguem uma tradição de interpretação da Psicologia Fisiológica Francesa de meados do XIX, um ramo do conhecimento que, segundo Daniela Barberis, compreende a relação de um sujeito com o mundo a partir do ato reflexo. ${ }^{20} \mathrm{~A}$ atividade psíquica, quando motivada por estímulos externos (ou necessidades físicas), nada mais é do que um mecanismo de estimulo-resposta. Interpretada como uma característica inata ao homem, sua eficácia é maior no meio do turbilhão das gentes "onde todas as imaginações são excitadas, e onde a unidade de tempo e de lugar apressa de um modo extraordinário, e quase fulminante, a alteração das impressões e dos sentimentos". ${ }^{21}$

Autores como 0 francês Théodule Armand Ribot (1839-1916) - patrono da psicologia fisiológica - determinam essa característica de forma bastante clara. É de autoria de Ribot o seguinte comentário: "A lei mais geral que rege os fenômenos psicológicos é a lei da associação. Por seu caráter compreensivo ela é comparável à lei da atração do mundo físico". ${ }^{22}$ Notemos aqui que Ribot, assim como Tarde, compara as atividades mentais associativas às conexões observáveis no mundo natural. Tal não ocorre ao acaso. É, fundamentalmente, uma leitura influenciada pelo filósofo Herbert Spencer (1820-1903) - também citado por Nina - e suas comparações entre as sociedades humanas e os organismos animais. ${ }^{23}$

Tendo em perspectiva esse modelo associativo, Tarde e Sighele, dois dos principais interlocutores de Nina, entendem que são os atos-reflexos que predominam em meio à coletividade. Ambos se apropriam, a partir deste terreno em comum, de duas leis gerais que explicariam o funcionamento da sociedade: a sugestão e a imitação. Estão preocupados em entender como essas duas grandes forças são capazes de entusiasmar uma coletividade sob a iniciativa de um sujeito, apto a manifestar suas intenções com habilidade e despotismo. Essa característica aglutinadora é algo essencial na formação das duplas, trios e demais ajuntamentos, que podem vir a alcançar dezenas de milhares de pessoas. ${ }^{24}$

A coletividade não tem outra ideia a não ser a que lhe insuflam e que se propaga "de um só ao cérebro de todos". 0 insuflador, para Tarde, é responsável por seus efeitos diretos, ainda que o motivo principal, qualquer que seja, ao se expandir, possa mudar de feição, intensificando-se "por uma espécie de progressão matemática" e o que era desejo moderado, torna-se paixão e fanatismo. A supraexcitação que se observa nestes casos é "em grande parte sua obra própria", mas também produto de um reflexo mútuo, de uma cooptação, de um trabalho co-executivo - entre individuo e coletivo. $^{25}$

0 papel do condutor das massas é algo imprescindível para Tarde e Sighele. A multidão quando em marcha deve sua existência à iniciativa deste personagem. Indispensável é a diferenciação entre condutor e conduzidos, entre meneurs e os menés. É preciso, portanto, levar em conta os caracteres individuais, evidenciar o papel de um sujeito habilidoso como orientador das massas. Alguém com persuasão e capaz de deixar "un popolo in catalessi!", como afirmou Sighele, para quem os agrupamentos humanos tem a tendência a "imitare la grande armonia dell'universo", que se reflete na "unione di sistemi planetari in cui un infinito numero d'astri minori girano attorno a dei soli". 26

Sighele afirma que esta forma de sugestão é o que possibilita o primeiro passo para a associação entre duas pessoas e depois a ampliação desse fenômeno para grupos de pequeno, médio e grande porte. Sighele concentra seus esforços em explicar o poder da sugestão que para ele é um axioma do processo de associação entre dois indivíduos: "Per noi è un assioma che l'associazione fra due individui — in qualunque campo essa si manifesti - è dovuta al fenomeno della sugestione". ${ }^{27}$

Pensamos que em Sighele a palavra "sugerir" tem por significado "inspirar" ou, em muitos casos, "impor" a outras pessoas predispostas certos hábitos, expressões, posturas e até pensamentos. Tal efeito não levaria um individuo 
"inconsciamente imitate dall'altro?", pergunta 0 autor. ${ }^{28}$ Por certo que sim, responde. Imitação e sugestão resumem em si essa característica peculiar de reprodução de um padrão de comportamento ou de um bloco de ideias vigorosas e persistentes. Perguntamo-nos então que sugestão e que imitação são essas, como foram instrumentalizadas por Tarde e Sighele e, por fim, como Nina Rodrigues se apropriou de tais categorias através destes autores.

Gabriel Tarde reformulou a concepção geral de imitation - até então utilizada como um recurso artístico ou literário - para explicar o mecanismo de propagação de algo novo e original pela sociedade dos homens. Tratou-a como uma condição básica da interação humana. Não uma lei universal e onipresente, mas uma "lei de contingência", imposta pelos atores que dela se utilizam para os mais variados propósitos e que, para Tiago Seixas Themudo, resume a forma como Tarde entendia o percurso de fluxos e tendências agregadoras em uma sociedade. ${ }^{29}$

Tarde torna-se o mais notório teórico deste que é um fenômeno regulador das iniciativas renovadoras e repetitivas. Estas ocorrem pelas mãos do homem, entendido como um "imitador por esencia". 0 sociólogo francês faz uma reflexão sobre como uma determinada sugestão constitui a própria razão da vida social, já que percorre um caminho "de persona a persona", e como o imitador desta sugestão é capaz de "hipnotizar" ou "magnetizar" um terceiro e assim sucessivamente: "esta cascada de sucessivas y encadenadas magnetizaciones es la regla". ${ }^{30}$

Interessa-nos particularmente a "magnetizacion" ou "electrización" de caráter "morboso" que, segundo Tarde, é "problema elemental y fundamental que la psicología sociológica (que comienza allí donde acaba la fisiológica) debe tratar de resolver" . ${ }^{31}$ Para isso ele procura definir "la substancia" que 0 ato de imitar comporta. Essencialmente, trata-se de uma "ideia", um "querer", um "juízo" ou um "propósito", em que se expressa certa dose "de creencia y de deseo, que es, em efecto, toda el alma de las palavras de una lengua, de las oraciones de uma religión (...)" ${ }^{32}$ Para Tarde 0 desafio vai além da compreensão de como, por exemplo, uma palavra é sugerida de um indivíduo a outro, mas sim como o primeiro se faz entender:

Si el oyente se hubiese limitado á repetir el sonido em cuestión como um papagayo, sin darle el sentido deseado, no se concibe como esta ecolalia superficial y mecánica habria podido conducirce á la inteligencia de la significación dada por um extranjero, y hacerle passar del sonido á la palavra”. (...) Seguramente, la admisión de tal postulado no debe ser difícil á quien conoce los esfuerzos hipnóticos, los milagros de la sugestión, tan vulgarizados em estos últimos tiempos. ${ }^{33}$

Os "esforços da hipnose" ou "milagres da sugestão" também fazem parte do repertório de Sighele, ao afirmar que a teoria sugestiva-imitativa seria capaz de explicar os casos de associação entre pessoas normais, criminosos e suicidas. Entre os alienados, a situação seria distinta. Para este autor, o louco (ou pazzo) não seria capaz de se unir a outro alienado, mas tão somente a um individuo são, estabelecendo, assim, a chamada Loucura a Dois, o embrião dos grandes ajuntamentos - uma manifestação social analisada por diversos autores, entre eles o alienista francês Henri Legrand du Saulle (1830-1886), citado por Sighele. ${ }^{34}$

0 individuo sugestionável, considerado ingênuo e geralmente destituído de inteligência, recebe impulsos e ideias desordenadas e confusas, passa a imitá-las continuadamente, sendo arrastado para a loucura de seu companheiro. A loucura compartilhada entre duas pessoas - os estudos de caso de du Salle o confirmariam -, não apresentam apenas, como poderia se supor, a coexistência de duas ilusões paralelas, mas semelhantes. Representam, antes, uma única empresa real, com objetivos claros e determinados.

Cria-se uma intricada relação entre dominante e dominado. A obediência de um ao outro não se dá por puro capricho, mas consiste, segundo Sighele, no misterioso fascínio pelo qual o sugestionado "manca del coraggio di ribellarsi, e la sua paura diventa rispetto, il suo odio si tramuta in amore". ${ }^{35}$ Sendo assim, o fenômeno da sugestão, seguido pelo fenômeno da imitação, com graus diversos de intensidade, se manifestariam nas quatro principais formas analisadas por Sighele: a coppia sana, a coppia criminale, a coppia suicida e, finalmente, a que mais nos interessa, e também a mais explorada por Nina Rodrigues, a coppia pazza (o par louco). 


\title{
A leitura aplicada de Nina Rodrigues
}

Nina Rodrigues inaugurou seus estudos sobre multidões com um texto intitulado Abasia coreiforme epidêmica no norte do Brasil, de 1890. ${ }^{36}$ Nele 0 autor examina uma epidemia coletiva de histeria que ocorreu em Itapagipe, subúrbio aprazível de Salvador, em 1882. 0 primeiro registro que se tem conhecimento sobre a moléstia apareceu em outubro deste mesmo ano na Gazeta Médica da Bahia. Era um pequeno texto sob o título Uma moléstia singular e que descrevia assim a enfermidade:

\begin{abstract}
As pessoas affectadas depois de caminharem naturalmente em apparencia por algum tempo, dobram de repente uma ou ambas as pernas, ou o tronco para um dos lados por alguns minutos, como se fossem cóxas, paralyticas, ou cambaleassem, continuando depois a marcha regular. (...) Não temos ainda informações exactas e minuciosas sobre esta epidemia de nova especie, que parece ir em progressivo desenvolvimento, mas esperamos obtel-as dos collegas que mais de perto a teem observado, bem como o juízo que tiverem formado ácerca da etiologia e danatureza da doença. ${ }^{37}$
\end{abstract}

Posteriormente, em abril de 1883, é publicado no mesmo periódico o relatório de uma junta médica organizada pela Câmara Municipal de Salvador para averiguar o caso da multidão de histéricos que tomou as ruas do bairro. Sob o título de Choreomania, trazia informações preciosas sobre a doença nervosa que levava a uma disfunção motora chamada coreia. De acordo com o documento a doença "transmite-se facilmente pelo que se chama contágio por imitação" . ${ }^{38}$

Seis anos mais tarde, em 1889, o assunto seria abordado pelo médico sergipano José Dantas de Souza Leite (1859-1925), em obra intitulada Études de pathologie nerveuse. ${ }^{39}$ Leite havia se formado em medicina na Bahia e em Paris, fez seu internato nos Asiles d'Aliénés de la Seine, foi sócio da Médico-Psychollogical Society de Londres e terminou a carreira clinicando no Rio de Janeiro. ${ }^{40}$ No capitulo V de Études..., intitulado Réflexions à propos de certaines maladies nerveuses observées à Bahia (Brésil), o autor traz a conhecimento duas pacientes suas que apresentaram sintomas semelhantes aos observados na epidemia de Itapagipe.

Segundo relatos, o bairro foi subitamente tomado por uma multidão de pessoas dançando e remexendo em um ritmo desordenado, espasmódico, sem sequência e ordenamento. Souza Leite chegará à conclusão de que as duas pacientes sob seu cuidado eram remanescentes do evento que se tornou conhecido como a epidemia de Itapagipe. A receptividade e a reprodução da afecção, em ambas, afirma Leite, se dá pela

(...) l'imitation, résultat préparé petit à petit par une suggestion inconsciente qui fut déterminée par le spectacle des contorsions de ses condisciples. La représentation des gestes et des mouvements devenait de plus en plus intense et impulsive parmi les faits de la mémoire de la malade jusqu'au jour où ils sont éclatés. ${ }^{41}$

Leite vê uma semelhança com outros casos registrados na Europa, no século XIX, como os histéricos de Friuli, Itália, de 1878 e os de Pledran, França, em 1881, descritos pelo médico Jean Marie Joseph Baratoux (1855-?). ${ }^{42}$ Apoiado em Charcot e no fisiologista francês Paul Richer (1849-1933) que publicaram, em 1883, um dos primeiros estudos sobre uma condição nervosa chamada astasia-abasia ${ }^{43}$ (impossibilidade de ficar em pé e de andar), seu diagnóstico também foi esse: “C' est dire que nous avons été en présence d'une petite épidémie d'abasie et d'astasie" ${ }^{44}$ As Américas, pelo que já tinha testemunhado, não estavam livres destes fenômenos: "(...) ces épidémies prennent déjà place dans la pathologie de quelques pays américains". 45

Frente a este caso, Nina Rodrigues vai procurar as causas primárias que teriam levado dezenas de milhares de pessoas, sob a influência da sugestão e da imitação, a apresentarem os mesmos sintomas mórbidos. A teoria sugestiva-imitativa proposta por Tarde e Sighele é, aqui, uma construção discursiva importante para Nina. Este, entretanto, não a assimilou integralmente. 0 autor maranhense vai afirmar que a significação dada por Sighele e Tarde ao "par louco" separado de "outras espécies de associações a dois tais como o par suicida, o par criminoso, etc., é por conseqüência 
inadmissível" ${ }^{46}$ Logo, também não haveria uma multidão vesânica distinta e paralela às outras espécies de multidões. Pelo contrário: há apenas uma única "multidão vesânica de formas múltiplas, oposta à multidão normal". ${ }^{47}$

Para sermos mais fieis ao pensamento de Nina, cabe dizer que para ele todas ou quase todas as espécies de multidão podem apresentar sintomas ora de normalidade, ora de insanidade. "A loucura não é mais do que o estado psicológico em que se pode encontrar uma espécie de multidão qualquer" ${ }^{48}$ Com efeito, Nina escreve que na nova fase em que entraram os estudos de psicologia coletiva, "fase começada por Scipio Sighele e tão brilhantemente desenvolvida por ele e outros autores, a parte concedida à influência da loucura foi muito inferior à que ela é na realidade". ${ }^{49} \mathrm{~A}$ loucura é, assim, um elemento central para Nina, enquanto psicólogo social para se pensar a respeito das multidões.

Ao passo que na operação lógica de Sighele as multidões se definem como tal, antes pelas leis da sugestão e da imitação, Nina Rodrigues toma por base seu caráter evidentemente patológico. Não havia como negar, obviamente, um processo que se desenrola com a sugestão de um individuo interessado, a imitação daqueles que 0 acompanham e o contágio pelas emoções exacerbadas. A inevitável cólera ordinária é esperada. No entanto, segundo Nina, Sighele

(...) deteve-se, porém, aí. Não pensou mesmo em pesquisar se este estado de furor é um estado anormal simples, ou, ao contrário, um verdadeiro estado patológico; não se preocupou absolutamente com suas conseqüências do ponto de vista da responsabilidade jurídica das multidões. ${ }^{50}$

A partir de leituras variadas, o médico maranhense estabeleceu alguns padrões de comportamento similares nas coletividades mórbidas. Ele cita, de partida, a obra clássica La folie à deux ou folie comunique, dos psiquiatras Ernest-Charles Lasègue (1816-1883) e Jules Philippe Joseph Falret (1824-1902)..$^{51} 0$ estudo - assim como 0 trabalho de Legrand du Saulle, já citado por nós - descreve a chamada Loucura a Dois, a forma "embrionária por excelência das manifestações em massa"52, um tipo de empreendimento conjunto simples, típico, exemplar, arquétipo e, portanto, de fácil demonstração. Na parceria entre dois indivíduos que partilham a mesma moléstia mental, se encontrava o primeiro grau de um fenômeno progressivo cujo resultado, respeitados certos condicionantes, é a loucura coletiva.

Embora houvesse a suspeita de que a associação entre alienados fosse uma realidade, 0 que mais interessava a Nina, era a possibilidade de os loucos se associarem com pessoas consideradas sãs. Para ele, a confirmação deste prognóstico poderia solucionar, quem sabe, algumas das principais questões que envolviam multidões em manifestações psicopatológicas públicas e/ou reservadas, como sessões de espiritismo e transes religiosos. Poderiam, enfim, esclarecer o fenômeno de disseminação de um delírio, de uma alucinação, de um devaneio entre uma população sugestionável, fraca, receptiva.

Uma pessoa, no controle de suas faculdades mentais, porém sujeita ao contágio através de um parceiro louco, denunciaria uma situação deste tipo, ou seja, uma situação de loucura imposta. Neste caso especifico, portanto, Nina sustenta a tese "largamente desenvolvida" de que os súcubos, isto é, os receptores passivos, ao contrário dos íncubos, os indutores ativos, "não são verdadeiros alienados" - pois parecem não haver "transposto os limites da loucura", ainda que não apresentem um estado mental inteiramente normal para os padrões então aceitos. As duas principais formas de loucura a dois abordadas até o momento - entre alienados e entre alienado e são -, inserem-se, assim, no seguinte quadro, elaborado por Nina:

$1^{\circ}$ Entre dois indivíduos sãos e normais; é a coppia sana, o par são de Sighele;

$2^{o}$ Entre dois indivíduos sãos, porém anormais; é o par criminoso, o par suicida, etc.;

$3^{o}$ Entre o alienado que tem aparências de razão e o indivíduo são, mas de inteligência limitada, que se torna apenas um convencido;

$4^{o}$ Entre o indivíduo alienado e o indivíduo são, mas predisposto e que se torna alienado;

$5^{\circ}$ Enfim, entre dois alienados. ${ }^{53}$ 
Nina afirma que imediatamente após a loucura a dois estão os casos de contágio doméstico ou familiar, onde um delírio pode alcançar mais de cinco pessoas. Segundo os critérios de Lasegue e Falret, há descrições de casos classificados como folie à trois, à quatre e então folie en famille. ${ }^{54} \mathrm{~A}$ partir daí, há um estágio superior a este, um pouco mais complexo, que envolve situações epidêmicas de "pequena escala". É o que representa, segundo Nina "as pequenas epidemias que explodem nas corporações religiosas, nos claustros, onde a aparente lucidez das pessoas atingidas pelo contágio alterna com francas manifestações de histeria, o que põe fora de dúvida a natureza mórbida dos acidentes". 55

Desses surtos menores, há como que um salto para as grandes epidemias de loucura que comportariam, por sua vez, um volume muito superior de pessoas envolvidas. Os grandes fenômenos de massa são o resultado da gradual evolução desses surtos circunscritos, dado que estes últimos "pela sua composição reproduzem rigorosamente as grandes loucuras coletivas" ${ }^{56}$ Condição necessária para a explosão destas últimas é a conformação do Estado de Multidão, termo sugerido por Nina a partir da obra do psicólogo e sociólogo Gustave Le Bon (1841-1931).

Com Le Bon a palavra multidão adquiriu significação particular nos novos estudos de psicologia coletiva, uma área do conhecimento impactada pelo enorme alcance de seus trabalhos. Isto porque 0 autor alertava seus atentos leitores para o perigo da anarquia das massas durante a Terceira República na França (1870-1940). Com as ruas tomadas por socialistas, sindicalistas, trabalhistas, sufragistas, entre outros, Le Bon foi, de alguma forma, a voz contrariada das elites politicas.

Neste ponto do texto, nos importa em lembrar como a multidão, com Le Bon, tornou-se, fundamentalmente, um termo genérico para identificar agrupamentos humanos homogêneos e heterogêneos. ${ }^{57}$ Sob os argumentos de um orador de prestígio, as afirmações violentas e os sentimentos excessivos apresentam-se sob a forma de uma imagem poderosa e nítida ou "acompanhada apenas de alguns fatos maravilhosos: uma grande vitória, um grande milagre, um grande crime, uma grande esperança" ${ }^{58}$ Nina Rodrigues, leitor de Le Bon, constrói sua concepção de multidão a partir destas ideias precedentes:

A multidão é, sobretudo, uma associação psicológica. É na aquisição de uma individualidade psíquica própria, diferente da constituição mental de cada uma das partes componentes, que reside a característica da multidão. Nela desaparecem as diferenças, as desigualdades, as individualidades, para a formação de uma unidade psicológica onde domina o caráter inconstante e impulsivo dos primitivos. ${ }^{59}$

Para Nina, este estado mental agudo das coletividades devia manifestar-se corriqueiramente nos povos primitivos e atrasados, caracterizado por uma exaltação emotiva "onde desaparece o controle da vida cerebral, e com ele, a personalidade consciente e 0 discernimento" ${ }^{60}$ Daí que, para além das características já citadas, Nina aprofunda sua análise e procura distinguir, agora, duas propriedades comuns aos ajuntamentos: as causas próximas, como uma excitação passional de momento e as causas distantes, ligadas, sobretudo, à herança étnica e racial.

\section{Causas próximas e causas distantes}

Indivíduos reunidos, agregados ao redor de um líder, atuando conforme padrões de comportamento sugestionados representavam, no final do século XIX, um fator de desestabilidade para as sociedades europeias. Esta visão pessimista sobre a atuação das "turbas" foi também assimilada no Brasil, através do discurso médico, pelas mãos de Nina Rodrigues. Preocupado, como vimos, com o caráter doentio das coletividades, Nina propõe-se a investigar com mais acuidade as causas primárias que fomentavam estes fenômenos.

Tendo à sua disposição um material empírico nativo, tal operação ocorreu com a divisão estabelecida entre causas "imediatas" e "longínquas" que influíam sobre um coletivo. Este arranjo - tendo como referência aqui as indicações do médico e historiador José Luis Peset -, é resultado de uma longa tradição de estudos médicos que 
remonta ao filósofo grego Cláudio Galeno (129-200). Mais conhecido como Galeno de Pérgamo, foi ele que criou 0 paradigma clássico do pensamento médico causal para explicar as doenças, divido em: aitía proêgoumenê (causa interna ou predisposta, vinculada à constituição do paciente); aitía prokatarktikê (causa externa ou excitante, ligada a atividades não-naturais, como excesso de comida ou de exercício); aitía synektikê (causa próxima ou conjuntural, ligada a eventos circunstanciais) ${ }^{61}$

Ainda que não hegemônico, o esquema galênico só verá mudanças efetivas com o advento de uma nova literatura médica na idade moderna, marcada pela preocupação em torno do crescimento das cidades, da expansão do comércio entre as nações, da multiplicação da massa trabalhadora, entre outros fatores. 0 filósofo e historiador Michel Foucault, citando o médico suíço Samuel Auguste André David Tissot (1728-1797), lembra que quanto mais complexo e tumultuado se tornava o espaço social, a saúde diminuía gradativamente, as "espécies" de doenças se diversificam e 0 burguês, configurado como agente social, sofria dos mais novos e variados "males dos nervos". ${ }^{62}$

Neste quadro complexo, a doença não era mais vista como algo derivado apenas do ambiente natural. Novos fenômenos mórbidos surgiam, em diferentes pontos da Europa e do mundo, forçando a formulação de uma nova etiologia causal que levasse em conta 0 aspecto coletivo e universal das doenças. Era necessária uma nova medicina classificatória e nesta "the galenic multicausal scheme" sobreviveu e difundiu-se, "although with quite a different content and interpretation". ${ }^{63}$

Essencialmente, constitui-se, com a contribuição de vários autores modernos - como Bernardino Ramazzini (16331714), Herman Boerhaave (1668-1738) e Johann Peter Frank (1745-1821) - um modelo causal divido, grosso modo, em três pontos e que alcança o século XIX: causas ambientais (naturais); causas provenientes do ambiente social e causas relacionadas à constituição biológica dos indivíduos. ${ }^{64}$ Suspeitamos que este seja o horizonte mais amplo que levou Nina Rodrigues - apoiado em uma literatura familiar, especialmente em Le Bon - a distinguir as causas próximas (ambiente social) das causas distantes (predisposição hereditária). Diz ele:

Sem dúvida o contágio mental por sugestão coletiva é o fator principal da constituição do estado de multidão e implica, como é obvio, não somente a preparação prévia pelas causas que podemos com Gustavo Le Bon, chamar distantes, mas ainda a excitação passional do momento por uma causa ocasional que pode ser qualquer uma das causas próximas deste autor. ${ }^{65}$

Iniciemos com os eventos de natureza que ressaltam e fortificam certas condições sentimentais e psicológicas circunstanciais. É nesses momentos, delicados e sensíveis, propícios à arregimentação das almas mais impressionáveis que atua, segundo Nina o "hábil meneur, advogado de talento, orador consumado", ${ }^{6}$ individuo com um senso de oportunidade único: "0 meneur não é mais, em suma, do que uma poderosa causa próxima, quer seja o catequizante, 0 verdadeiro chefe, o diretor ostensivo da multidão, quer seja o diretor inconsciente representado pelos mais exaltados e conseqüentemente pelos mais sensíveis às sugestões ambientais anônimas". ${ }^{67}$

Geralmente esse personagem de destaque é classificado por Nina como um alienado capaz de estabelecer algum tipo de comunicação com pessoas sãs. 0 médico se indaga: "pondo de parte os meneurs desequilibrados, neuropatas e verdadeiramente alienados", não seria possível que o estado de multidão provocasse uma "manifestação de loucura transitória" entre indivíduos normais, mas predispostos por seu temperamento? Sua resposta é clara: "0 estudo das paixões humanas demonstra que sua violência pode provocar um verdadeiro estado delirante transitório durante 0 qual 0 indivíduo perde todo o discernimento e a consciência dos seus atos". ${ }^{68}$

Um dos casos analisados por Nina foi exposto no texto A loucura epidêmica de Canudos: Antônio Conselheiro e os jagunços, de $1897 .{ }^{69}$ Conselheiro era forte candidato a meneur das multidões, homem afligido por uma vesânica latente "perfeitamente diagnosticável". Foi em um meio "sociologicamente instável", ou melhor, em uma "fase sociológica marcada por uma crise social e religiosa" que "Antônio Maciel cavou os fundos alicerces do seu poderio material e espiritual quase indestrutível" ${ }^{70}$ As populações "nômades e guerreiras" do nordeste viviam à mercê "desse prestígio moral que desbanca, a ligeiro aceno, toda a influência espiritual do clero católico".71 
Para Nina, Antônio Conselheiro "é seguramente um simples louco". ${ }^{72}$ Porém, nota o médico

(...) alguma coisa mais do que a simples loucura de um homem era necessária para este resultado e essa alguma coisa é a psicologia da época e do meio em que a loucura de Antônio Conselheiro achou combustível para atear o incêndio de uma verdadeira epidemia vesânica. ${ }^{73}$

Segundo Nina, a associação e a comunicabilidade de pessoas enfermas e predispostas que levam ao compartiIhamento da loucura são "o reflexo senão de uma época pelo menos do meio"74 de que fazem parte. Os predispostos já estão, em muitas ocasiões, presos a uma vesânia oculta e implícita. Bastaria uma causa próxima e imediata para desencadear uma explosão de histeria coletiva. A causa imediata ou a "impulsão psicológica" é, aqui, personificada por Conselheiro.

A sua loucura seria compatível com uma paranoia primitiva, nada mais do que o delírio crônico de evolução sistematizada do psiquiatra francês Jacques-Joseph-Valentin Magnan (1835-1916). Essa categoria nosográfica estava, segundo Maria Oda, no centro das discussões europeias ao redor da paranoia, à época em que Nina escrevia. Apresentado em 1893, nas Leçons Cliniques sur les Maladies Mentales, o delírio era diagnosticado por Magnan a partir da identificação de quatro fases progressivas e degenerativas. ${ }^{75}$ Em relação a Conselheiro, o diagnóstico feito por Nina se deu pelas seguintes circunstâncias: "a longa duração do delírio, suas transformações em fases bem distintas, a sistematização delirante perfeita, as alucinações do alienado". ${ }^{76}$ Nina identifica ao longo da vida de Antônio Maciel os mesmos estágios "admitidos na marcha da psicose primitiva".

Com base nessas assertivas, diz Nina: “Compreende-se assim que a intensidade das emoções, exagerada pelo crescimento das aglomerações e pela repercussão sugestiva dos sentimentos que dominam a multidão, e que se produz nos meneurs, seja suficiente para transformar a cólera dos chefes de multidão em um estado francamente patológico". ${ }^{77}$ Essa loucura que agrega também se deu na epidemia coletiva em Itapagipe, em Salvador, no ano de 1882, já citada neste texto. Itapagipe trouxe à luz o parecer da comissão de médicos organizada pela prefeitura para averiguar 0 caso. 0 relatório da junta, chefiada pelo Dr. José Luiz de Almeida Couto, ${ }^{78}$ falava sobre uma doença nervosa incluída na classe das coreias que, até então circunscrita aos trabalhadores da Fábrica de Tecidos da Penha, se espalhou por todo 0 "arrabalde":

As primeiras manifestações conservaram-se durante algum tempo limitadas, circumscriptas; logo, porém, que a affluencia de moradores e visitantes aquelle bairro foi crescendo com a aproximação do tempo de festa, logo que a moléstia foi chamando mais a attenção sobre si, os casos foram se multiplicando, e o mal estendeu-se como actualmente o conhecemos. ${ }^{79}$

As chamadas coreias - que, atualmente, possuem diferentes variedades e sintomas distintos, como a coreia de Sydenham, de Huntington, entre outros subtipos - não explicavam, entretanto, a sucessão de danças e contorcionismos em massa testemunhados por populares. Havia um precedente semelhante em São Luiz do Maranhão, na década anterior, de 1870, informada pelo médico Afonso Saulnier de Pierrelevée (1830-?), colega de Nina, porém, sem a gravidade e 0 alcance da similar baiana.

0 parecer dos médicos trazia a informação de que moléstias nervosas desse tipo "reinaram epidemicamente desde remotíssimas épocas" na Europa. Ainda que as diversas causas que transformaram a doença em "verdadeiros flagelos de países e nações inteiras" não existissem no Brasil ou por aqui estivessem atenuadas, as semelhanças não podiam ser ignoradas. "Ainda hoje", disseram os pareceristas baianos, em diversas localidades da Europa:

Fidedignas narrações dizem-nos o que foi a dança de S. Guido ou de S. Vito na Bélgica, na Holanda, na Alemanha desde o século undécimo; epidemias análogas produziram a tarântula na Itália, o tigre tier na Abissínia, o convulsionismo em França e a dança macabra em diversos países. ${ }^{80}$ 
0 documento atestava, e isto é de fundamental importância para este trabalho, que todos os historiadores estariam de acordo em vincular a gravidade e a extensão destas epidemias "aos meios sociais da época" ou às "práticas incontestavelmente errôneas" que as acompanhavam. Importa sublinhar que práticas seriam estas:

\begin{abstract}
Os ajuntamentos dos enfermos em romarias ou para solicitarem a compaixão pública; a idéia falsa de que a moléstia era uma espécie de desejo irresistível de dançar e que só na dança não interrompida e cada vez mais convulsa e desordenada estaria a saciedade desse desejo e uma suposta melhora; a prostração que se sucedia a este delírio crescente do movimento e que naturalmente exercia sobre o espírito desses indivíduos e sobre a própria inervação uma influência progressivamente mais grave; as práticas religiosas que faziam dos atacados outros tantos possessos; tudo isso contribuiu para deixar daquelas epidemias tais impressões que ainda hoje celebra-se nas províncias do Reno, não obstante as tentativas do Governo e do clero com o fim de aboli-la, uma popularíssima procissão, chamada das cabras, em que todo préstito dirige-se ao templo a dar três pulos para diante e um para trás, movimentos que recordam, em mau arremedo, as desordens de locomoção dos antigos enfermos. ${ }^{81}$
\end{abstract}

No caso brasileiro, Nina considera que se o parecer da comissão médica tornou os fatos históricos em si bem conhecidos, a contribuição para os estudos clínicos, por outro lado, resume-se às observações do Dr. Souza Leite, também já citado neste texto. 0 médico diagnostica duas pacientes suas remanescentes da epidemia com abasia-astasia, mas não dá indicações claras que expliquem a disseminação da moléstia pela população de Itapagipe. É possível apenas conjecturar que Leite associa uma possível prevalência da doença com as práticas religiosas da população devido ao destaque que ele dá às palavras com que Charcot inicia a sua lição sobre espiritismo e histeria e que, em sua opinião, todo neuropatologista deveria ter à disposição para consulta em seu gabinete:

Il est incontestable que tout ce qui frappe vivement l'esprit, tout ce qui impressionne fortement l'imagination, favorise singulièrement, chez les sujets prédisposés, l'apparition de l'hystérie. Parmi tous ces traumatismes des fonctions cérébrales il n'en est peut-être point de plus efficace et dont l'action ait été plus souvent signalée, que cette croyance au merveilleux, au surnaturel, qu'entretiennent et qu'exagèrent, soit les pratiques religieuses excessives, soit dans un ordre d'idées connexes, le spiritisme et sa mise en oeuvre. ${ }^{82}$

Somando à obra de Souza Leite, as reflexões do francês otorrinolaringologista Maurice Lannois (1856-1942) e do neuropatologista francês Paul Oscar Blocq (1860-1896), Nina chega à conclusão de que se tratava de uma doença do grupo das chamadas Grandes Coreias e que poderia ser denominada abasia coreiforme. Segundo o médico maranhense, o caráter epidêmico da moléstia que atingiu Salvador a aproximaria da conhecida dança religiosa de "Saint-Guy", ou "Dança de São Guido". ${ }^{83}$

Seus primeiros registros recuam aos séculos $\mathrm{X}$ e Xl, com reincidências nos séculos XIV e XV em pontos distintos da Europa. ${ }^{84} \mathrm{Na}$ idade moderna, para solucionar o problema, autoridades de vários países recorreram à violência e ao exorcismo, tentativas estas infrutíferas, levando o povo a recorrer à interseção de veneráveis santos, entre eles Vitus ou Vito (?-303 d.C), mártir católico quando vítima da perseguição do Imperador Diocleciano (245 d.C.-313 d.C.). Segundo a tradição popular Vitus "demandé à Dieu de préserver de la chorée tous ceux qui célébreraient l'anniversaire de sa mort". 85

Quer a Comissão Médica, quer o Dr. Sousa Leite, a par das ultimas novidades no campo da psicologia coletiva, defenderam que a epidemia havia se alastrado pelo mecanismo do contágio por imitação e/ou sugestão. Nina concordou com este 0 diagnóstico, mas ressaltou:

Parece-me, porém, que ficou de aplicação muito restrita e local a apreciação das causas que prepararam o terreno, sem o qual de nenhum efeito teria sido a imitação (...) é necessário remontar a causas mais gerais e admitir que pairava no ambiente brasileiro alguma coisa de anormal que, atuando sobre a população do país de modo a enfraquecer o organismo e exaltar as faculdades psíquicas, a predispôs a ponto de casos isolados de abasia coreiforme poderem tomar de um momento para outro as proporções de uma epidemia tão extensa $(\ldots)^{86}$ 
Em sua opinião, as raízes da epidemia deveriam ser investigadas nas influências mesológicas e nos "fenômenos sociais complexos que se prendem à fase histórica porque passa o nosso país". No primeiro grupo estavam incluídos os fatores advindos da circunscrição da epidemia ao norte do Brasil, frutos da "decadência notória em que se acha esta porção da República". Temos, assim, o calor abrasador do nordeste que "prodigaliza às populações do Norte a indolência e a anemia"; as condições sanitárias e higiênicas "pouco lisonjeiras" e o desaparelhamento da região para lidar com a forte repercussão das revoluções político-sociais de seu tempo. ${ }^{87}$

No segundo grupo Nina dá destaque aos fenômenos de ação/reação da população frente à "revolução política" do final do XIX. As reformas institucionais do país - sobretudo "a vitória do abolicionismo e as suas desastradas conseqüências econômicas" - se deram com uma "aceitação tácita e sem protesto" do povo. Quer se interprete esses fatos no sentido de uma "condenação e surda revolta de longa data", quer no sentido de um "indiferentismo e descrença necessariamente mórbidos", característicos de um povo ainda no berço, para Nina, "do ponto de vista médico em que me coloco têm eles um valor sensivelmente igual" ${ }^{88}$

Esses condicionantes são causas próximas, atuantes, muitas vezes imediatas, as "paixões arrebatadoras", os "choques emotivos" e que se distinguem das causas que atuam em longo prazo. Estas, por sua vez, são vinculadas à herança étnica e racial, à preponderância do negro e do índio nas raízes da formação da sociedade brasileira, em geral, e baiana, em particular. Nina entrevia na mestiçagem um fenômeno ainda em vias de se completar no Brasil. Era 0 resultado de um quadro calamitoso de reunião de "raças em graus diversos de civilização". Uma fusão extremamente perniciosa, tendo em vista que os tipos brasileiros estavam "em períodos muito desiguais da evolução sociológica".

Seguindo a sugestão de Le Bon, Nina enxerga no fator racial um diferencial que merece atenção à parte. Le Bon é claro quanto a esta questão ao dizer que "este fator, a raça, deve figurar na primeira linha, porquanto, por si só é muito mais importante que todos os outros" ${ }^{89}$ Para este autor:

A vida consciente do espirito representa apenas uma fração diminuta em confronto com sua vida inconsciente. (...) Os nossos atos conscientes procedem de um subtractum inconsciente formado, sobretudo, de influências hereditárias. Esse substractum encerra os inúmeros resíduos ancestrais que constituem a alma da raça.90

Nina Rodrigues oferece ao leitor algumas pistas sobre a preponderância de fatores raciais no seu quadro de explicação. No capitulo III do segundo livro de sua autoria, intitulado 0 animismo fetichista dos negros baianos, ele aborda, em pouco mais de uma página, o tema da epidemia de Itapagipe. ${ }^{91}$ Seu esforço é no sentido de utilizar este evento singular para provar, entre outras coisas, que o fundo "nevropathico ou hysterico do negro" era característica saliente entre a população baiana.

A presença ou não da histeria entre os negros mantinha-se como tema de fortes embates à época da escrita desses textos. A superstição excessiva do "áfrico-bahiano" que sob a influência dos sonhos, não conseguiria distinguir entre 0 real e 0 imaginário, confundia um sonho corriqueiro com a manifestação de entidades desencarnadas ou de espíritos de amigos mortos, era sinal de que o "mysticismo nevrophatico" podia ser detectado.

Mas, exemplos deste tipo, relacionados com fenômenos como sonambulismo, haviam de oferecer apenas provas "indiretas" da presença da histeria entre o povo negro da Bahia. Já era hora de apontar "casos incontestes" de histerismos na população africana. Se "alguma duvida ainda pudesse subsistir" a respeito da força da histeria, bastava atentar-se para o papel "salientíssimo e preponderante" que teve a raça negra na "grande endo-epidemia de abaxia-choreiforme", isso seria "mais que sufficiente para desfazel-a em médicos e profanos". Para Nina a propagação da histeria entre os negros era um fato notável, tendo ele próprio "conhecimento de explosões da epidemia coreiforme, quando já se tinha ella generalizado, em diversos candomblés e sambas". ${ }^{92}$

Em 1901 Nina publica um novo estudo com o titulo de A loucura das multidões ou La folie des foules, no original. ${ }^{93}$ Dividido em diversos itens, ou melhor, em diferentes "observações", importa-nos aqui a "observação III", cujo titulo é Abasia coreiforme epidêmica que grassou no Norte do Brasil. Nela o médico maranhense foca sua atenção no que 
poderia ter "influído poderosamente" para o desenvolvimento da epidemia: a "predominância numérica da raça negra e de seus mestiços em nossa população".

Está claro para Nina que a histeria desses "seres híbridos" só vicejava em meio a uma população predisposta, marcada física e intelectualmente pela herança étnica e racial. Le Bon, sempre lembrado por Nina, fala de "fatores remotos" capazes de tornar as multidões susceptíveis a certas convicções e inaptas a outras: "Preparam o terreno em que se veem de súbito germinar novas ideias, cuja força e cujos resultados surpreendem, mas cuja espontaneidade é apenas aparente. (...) É isso apenas um efeito superficial, cujo longo trabalho anterior cumpre geralmente explicar. (...)" ${ }^{\prime 94}$

Notemos, assim, que dois elementos atuam conjuntamente nas coletividades: por um lado, as "paixões de espírito", as "impulsões psicológicas", a "cólera patológica", temporalmente mais próximas dos fatos relatados, mais efêmeras e permutáveis, vivenciadas em tempos de festas e celebrações e por outro, a marca da raça, um fator mais arraigado, enraizado. 0 fenômeno que as unem é a religião. Daí que para Nina o "fetichismo negro" ou a "astrologia aborígene" são fundamentais, enquanto devoções e práticas religiosas que incrementam o avanço de uma epidemia coletiva.

\section{Religiosidade: onde as causas se encontram}

Haveria de ter algum elemento com força suficiente para incrementar os caracteres de sugestionabilidade de uma afecção mental, capaz de pulverizar a "exaltação delirante" entre um determinado grupo de pessoas impressionáveis, algo responsável por dar "liga" a uma moléstia que se espalhou desenfreadamente, como foi o caso do histerismo de Itapagipe. Supomos que esse elemento, crucial para a nosografia da moléstia, seja a religiosidade, ou a morbidez religiosa - para ser mais fiel ao vernáculo médico-cientifico em vigor na época.

Tendo em mente as inúmeras condições do "meio social" que Nina já apontou anteriormente; os laços entre histeria e religiosidade observados por Souza Leite; os indicativos de que Le Bon é sua referência habitual; e seus inúmeros trabalhos focados na religiosidade afro-brasileira, escritos concomitantemente ou posteriormente aos das multidões; tomar o "caráter religioso" dos movimentos como algo diferenciado no quadro nosológico parece verossímil. Vejamos de que forma Nina Rodrigues tenta explicar, por exemplo, como alguns povos escaparam do "contágio formidável" das cruzadas medievais, uma "estranha e colossal" psicose epidêmica que grassou por toda a Europa medieval:

\footnotetext{
Devemos por conseqüência admitir que a doença só pôde atingir a forma epidêmica com o concurso de certas condições psicológicas do meio social onde se manifestou, e que deram à sugestão o poder de provocar, pelo contágio moral, a reprodução, a multiplicação dos casos. (...) Este fato não é um caso particular das epidemias psíquicas de manifestações motoras, mas antes uma regra geral das psicoses epidêmicas. Nessa psicose epidêmica da idade média, estranha e colossal que foram as cruzadas, houve povos que escaparam ao contágio formidável, graças a suas condições psicológicas de momento. Michaud, citado por Sergi, observou que se as prédicas de Urbano II não exerceram a menor influência sobre os italianos, isso se deve às preocupações mercantis e às lutas locais pela liberdade. As preocupações religiosas, gérmen e alimento da psicose [grifo nosso], estavam em segundo plano. ${ }^{95}$
}

Essas manifestações são propicias à disseminação de doenças nervosas contagiosas e Nina tenta provar isto ao citar casos complexos de epidemias vesânicas em que as desordens motoras se aliavam a distúrbios delirantes, com componentes religiosos. São seus os exemplos das "pregações na Suécia (1840); a epidemia de Morzine na Alta-Savóia (1861); a de Verzegnies (1858); os revivals, campmeetings, etc;" . ${ }^{96}$ Em Itapagipe, as danças, reuniões, festas e celebrações determinaram o avanço da epidemia. No relatório da Comissão Médica de 1883 evidências neste sentido já aparecem. As primeiras manifestações da coreia de Itapagipe mantiveram-se delimitadas ao bairro, mas com a "aproximação do tempo de festa" a moléstia chamou para si mais atenção, "os casos foram se multiplicando e o mal estendeu-se como atualmente o conhecemos". 
Nina segue o mesmo raciocínio: só em 1882, é que a moléstia fez sua aparição na Bahia, no arrabalde de Itapagipe, começando por alguns casos que se multiplicaram no fim do ano e no começo do ano seguinte, por ocasião das festas populares que atraem e fazem afluir a este ponto uma grande parte da população. ${ }^{97} \mathrm{Na}$ Bahia, segundo Nina, não é raro ver um coreico provocar a moléstia em certo numero de pessoas, ao marcar presença "em certas festas populares, principalmente religiosas". ${ }^{98}$

A própria comissão investigadora aponta para indícios desta natureza. 0 trânsito de pessoas atacadas pelas ruas da cidade; 0 ajuntamento popular nas duas ruas contíguas à capela do Rosário; a celebração de "uma série de festas" onde a maioria da população da cidade "se entrega a toda sorte de fadigas de corpo e impressões de espírito", tudo concorrendo "para a disseminação da moléstia e para dar-Ihe o caráter epidêmico". Trechos como estes serviram para Nina mostrar que o cortejo dos coreicos se agigantava nas prolongadas festividades religiosas, características da população carente, supersticiosa e, sobretudo, miscigenada.

Devido ao seu intenso caráter de sugestionabilidade, as danças e, sobretudo, as danças sagradas a que se entregam "tão apaixonadamente", os negros constituiriam "um poderoso agente provocador da histeria". Diz ele:

\begin{abstract}
As contorções que se apoderam dos negros durante essas danças já por si mesmas têm um caráter coréico, e sabe-se que em mais de um ponto da cidade foram estes exercícios coreográficos a fonte do desenvolvimento ou do recrudescimento da doença; não se deve esquecer, aliás, que nas duas cidades brasileiras onde a doença tomou grandes proporções, é muito elevado o número dos negros e seus mestiços. ${ }^{99}$
\end{abstract}

Parece-nos que Nina está apontando para o fato de que a população negra e mestiça da Bahia é extremamente sugestionável. Por esta razão, quando em festa e celebração, seus indivíduos transmitem a doença de forma contagiosa, através, sobretudo, dos movimentos corporais. Atentemos para o fato de que Nina Rodrigues pontua, detalhadamente, as circunstâncias, os eventos sociais e o conjunto de crenças e desejos que se intercruzaram em determinado momento da história para criar as condições que levaram à disseminação de uma moléstia nervosa em Salvador, na Bahia.

Raciocínio análogo ele utilizará em texto de 1899, 0 regicida Marcelino Bispo; assim como nos outros casos relatados na obra A loucura das multidões, a saber: a "observação II" (anterior à da epidemia de Itapagipe), intitulada de Loucura coletiva numa sessão de espiritismo em Taubaté, ocorrida em 1885; a "Observação IV", intitulada Epidemia de loucura religiosa em Canudos; história médica do alienado meneur; e a "Observação V", intitulada $A$ hecatombe de Pedra Bonita em Pernambuco, movimento fanático-religioso ocorrido entre 1836-1838 - eventos estes que serão analisados em uma próxima oportunidade.

\title{
Considerações finais
}

A matriz racial fixa apontada por Nina, não o impediu, como vimos anteriormente, de tratar a questão das multidões também pelo prisma sociológico e psicológico. 0 contrário é que nos parece verdadeiro: à esta corrente fatalista que condenava a presença do negro e do mestiço na população brasileira, somou-se, pelas mãos do médico maranhense, uma vertente de estudos mais flexível, mas nem por isso menos pessimista, que incluía entre as causas de uma epidemia coletiva as influências do meio social e suas contingências naturais.

Usualmente, são apontadas, de forma crítica, como o fez recentemente Anadelia Romo, as incongruências desse modelo teórico e sua miscelânea de conceitos que, em ultima instância, seriam incompatíveis. ${ }^{100}$ Não consideramos Nina Rodrigues, entretanto, nem um "radical do pessimismo", como afirmou Lilia Schwarcz ${ }^{101}$, nem um radical do relativismo. Isto porque ele se tornou sim um propagador de ideias que negavam o determinismo biológico, sem que isso invalidasse, necessariamente, toda a tradição de estudos científicos assentados neste mesmo corpo de conhecimentos determinista. 
Notamos que Nina não considerava incoerente um discurso que incorporasse o racialismo, por um lado, e as propostas sócio-psicológicas, por outro. Seus trabalhos sobre as multidões no Brasil tornaram-se um reflexo desse modo de pensar e demonstram a habilidade de Nina ao interpretar casos nativos a partir de referências teóricas estrangeiras. Levando em consideração a sua familiaridade com os autores europeus, tudo indica que Nina tentou dialogar diretamente com seus pares do ultramar, mas reservando-se o direito de construir um discurso autêntico e inovador.

Seus textos revelam a posição privilegiada e não menos problemática de um pesquisador que vivia em um país mestiço, "desordenado" e como esse lócus de atuação era, contraditoriamente, sua principal vantagem, seu foco de atuação e reflexão. Os problemas que faziam do Brasil um lugar condenado ao atraso, também faziam dele um laboratório que permitia a Nina conversar de igual para igual com o centro de produção intelectual de sua época, a Europa.

\section{Notas e referências bibliográficas}

Filipe Pinto Monteiro é doutorando pelo Programa de Pós Graduação em História das Ciências e da Saúde (PPGHCS) da Fundação Oswaldo Cruz (FIOCRUZ). Esta pesquisa recebeu apoio financeiro da FIOCRUZ. E-mail: filipemhst@gmail.com

1 RAMOS, Artur. Prefácio. In: RODRIGUES, Raimundo Nina. As coletividades anormais. Brasília: Senado Federal, Conselho Editorial, 2006, p. 10

2 RODRIGUES, Raimundo Nina. Os mestiços brazileiros. Brazil Médico, Rio de Janeiro, fev./mar. de 1890; salteador Lucas e o de um índio assassino. Gazeta Médica da Bahia, Salvador, ano XXIV, n. 9, março de 1892;

Estudos de craniometria. 0 cranco do 0 animismo fetichista dos negros baianos. Revista Brazileira, Rio de Janeiro, 1896; . . Métissage, dégénéréscence et crime. Archives d Anthropologie Criminelle. Lyon, 1899; . La paranoïa chez les nègres. Archives d'Anthropologie Criminelle, de Criminologie et de Psychologie Normale et Pathologique, Lyon, ano 18, n. 118, p. 609-651 e n. 119, p. 689-714, 1903; Os africanos no Brasil. São Paulo: Companhia editora Nacional, 1932.

3 CORRÊA, Mariza. Raimundo Nina Rodrigues e a "garantia da ordem social". Revista USP, São Paulo, n. 68, p. 131, dez.-fev. 2005/2006.

4 CORRÊA, Mariza. Os livros esquecidos de Nina Rodrigues. Gazeta Médica da Bahia, Salvador, n. 76, suplemento 2, p. 62, 2006.

5 Ibidem.

6 ODA, Ana Maria Galdini Raimundo. Sobre o diagnóstico diferencial entre a histeria e a beribéri: as epidemias de caruara no Maranhão e na Bahia, nas décadas de 1870 e 1880. Revista Latinoamericana de Psicopatologia Fundamental, São Paulo, ano VI, n. 4, p. 140, dez. 2003.

7 DALGALARRONDO, Paulo. Estudos sobre religião e saúde mental realizados no Brasil: histórico e perspectivas atuais. Revista de Psiquiatria Clínica, São Paulo, n. 34, suplemento 1, p. 25-33, 2007.

8 CORRÊA, Mariza. Raimundo Nina Rodrigues e a "garantia da ordem social". Revista USP, São Paulo, n. 68, p. 139, dez.-fev. 2005/2006.

9 CORRÊA, Mariza. As ilusões da liberdade: a escola Nina Rodrigues e a antropologia no Brasil. Bragança Paulista: Edusf, 1998; FONSECA, Pedro Henrique Miranda. 0 sanitarista Nina Rodrigues. Suplemento Cultural da Associação Paulista de Medicina, São Paulo, n. 99, jul. 1995; JACOBINA, Ronaldo Ribeiro e CARVALHO, Fernando Martins. Nina Rodrigues, epidemiologista: estudo histórico de surtos de beribéri em um asilo para doentes mentais na Bahia, 18971904. História, Ciências, Saúde - Manguinhos, v. VIII, n. 1, p. 113-32, mar.jun. 2001.

10 Para citar alguns dos mais representativos no conjunto de sua obra: RODRIGUES, Raimundo Nina. A nova agricultura e o regimen alimentar do norte. Pacotilha. Jornal da Tarde, São Luiz, 5, 9 e 18 de jun./6 e 9 de jul. de 1888; . Contribuição para o estudo da lepra no Maranhão. Gazeta Médica da Bahia, Salvador, set. e nov. 1888/jan., fev., mar., set., nov., dez. de 1889/abr. 1890; _ A organização do serviço sanitário no Brazil. Gazeta Médica da Bahia, Salvador, ano XXIII, n.3, setembro de 1891; A epidemia de influenza na Bahia em 1890. Gazeta Médica da Bahia, Salvador, ano XXII, n.12, junho de 1891; __. A organização dos serviços de hygiene publica e de vaccinação no Estado da Bahia. Gazeta Médica da Bahia, Salvador, ano XXIV, n.2 e 3, ago./set. de 1892; . As raças humanas e a responsabilidade penal no Brasil. Bahia: Edição Econômica, 1894; brasileiro. Bahia: Imprensa Moderna, 1901.

11 LINS E SILVA, Augusto. Atualidade de Nina Rodrigues. Estudo bio-bibliográfico e crítico. Rio de Janeiro: Cia. Editora da Leitura, 1945, p. 31.

12 CARNEIRO, Edison. Ladinos e crioulos. Estudos sobre o negro no Brasil. Rio de Janeiro: editora Civilização Brasileira, 1964, p. 108 e 216 . (Retratos do Brasil, v. 28).

13 MUNNÉ, Frederic. La construcción de la Psicología Social como ciencia teórica. Barcelona: Alamex, 1989; GINNEKEN, Jaap Van. The 1895 debate on the origins of crowd psychology. Journal of the Hisiory of ihe Behavioral Sciences, v. 21, p. 375-382, October, 1985.

14 LIMA, Lamartine de Andrade. Roteiro de Nina Rodrigues. Ensaios/pesquisas 2, Centro de Estudos Afro-Orientais, Salvador, abril de 1984.

15 TARDE, Gabriel. Monadologia e sociologia - e outros ensaios. São Paulo: Cosac Naify, 2007.

16 VARGAS, Eduardo Viana. Antes tarde do que nunca: Gabriel Tarde e a emergência das ciências sociais. Rio de Janeiro, Contra Capa, 2001; A microssociologia de Gabriel Tarde. Revista Brasileira de Ciências Sociais, n. 27, p. 93-110, 1995

17 VARGAS, Eduardo Viana. Multiplicando os agentes do mundo: Gabriel Tarde e a sociologia infinitesimal. Revista brasileira de Ciências Sociais, São Paulo, v.19, n. 55, p. 175, jun. 2004. 
BOSC, Olivier. De la folla delinquente à la follacultura: Scipio Sighele et Pasquale Rossi prophètes italiens de la modernité au tournant du siècle. Laboratoire italien. Politique et societé, Lyon, n. 4, p. 37-56, 2003.

19 SERGI, Giuseppe. Antropologia e scienze antropologiche. Messina: C. de Stefano, 1889.

20 BARBERIS, Daniela Silvia. Indivíduo e personalidade na psicologia fisiológica francesa do final do século XIX. 1992.318 f. Dissertação (Mestrado em Antropologia Social). Museu Nacional, Universidade Federal do Rio de Janeiro, Rio de Janeiro, 1992.

21 SIGHELE, Scipio. A multidão criminosa. Ensaio de psicologia coletiva. Rio de Janeiro: Organização Simões, 1954, p. 36 . (Coleção livros de ontem e hoje).

22 RIBOT, Théodule Armand. La psychologie anglaise contemporaine. Paris: Félix Alcan, 1870, p. 423-424 Apud BARBERIS, Daniela Silvia. op. cit., p. 22. Ver também RIBOT, Théodule Armand. The psychology of the emotions. Nova York: The Walter Scott Publishing Co., 1897.

23 SPENCER, Herbert. Les premiers principes. Paris: Félix Alcan, 1888 Apud RODRIGUES, Raimundo Nina. As coletividades anormais. Brasília: Senado Federal, Conselho Editorial, 2006, p. 55.

24 SIGHELE, Scipio. La coppia criminale: psicologia degli amori morbosi. Turim: Torino Fratelli Bocca Editori, 1897.

25 TARDE, Gabriel. As multidões e as seitas criminosas. In: . A opinião e as massas. São Paulo: Martins Fontes, 2005, p. 143 a 147.

26 SIGHELE, Scipio. op. cit, p. 4.

27 Idem, p. 80

28 Idem, p. 22

29 THEMUDO, Tiago Seixas. Gabriel tarde. Sociologia e subjetividade. Rio de Janeiro: Relume-Dumará, 2002 , p. 57 e 58.

300 termo "magnetização" aqui remonta, ainda que indiretamente, ao médico alemão Franz Anton Mesmer (1734-1815) autor da teoria do magnetismo animal. Concebida também como mesmerismo, em essência, propunha a existência de um "fluido" magnético que percorreria o corpo humano. Mesmer dizia ser capaz de manipular este fluido, como uma corrente elétrica, para fins terapêuticos. Posteriormente, o médico e aristocrata francês Amand-MarieJacques de Chastenet, o marquês de Puységur (1751-1805), discípulo de Mesmer, descobriu um novo estado de consciência, ao magnetizar os seus pacientes, o estado de sono, ou sonambulismo.

Controversa, a cultura magnético-sonambúlica só será contestada na década de 1840 pelo médico escocês James Braid (1795-1860) que não comprovou a existência do fluido magnético. Propôs, por outro lado, um fato de ordem mecânica baseado unicamente na fisiologia do cérebro e que ele denominará de Hipnotismo. Este sim, um termo mais próximo aos escritos de Gabriel Tarde que admite que quando escreveu o seu trabalho sobre imitação pela primeira vez, a hipnose ainda não havia se firmado no campo cientifico. Ver CARROY, Jacqueline e PLAS, Régine. The origins of French experimental psychology: experiment and experimentalism. History of the Human Sciences, London, Sage (London, Thousand Oaks and New Delhi), vol. 9, n. 1, p. 79, 1996; YEATES, Lindsay Bertram. James Braid: Surgeon, Gentleman Scientist, and Hypnotist. 2013. 829f. Thesis (Doctorate in Philosophy). Faculty of Arts \& Social Sciences, University of New South Wales, Sydney, Australia, 2013; TARDE, Gabriel. Op. Cit., p. 102, 103 e 111.

31 Idem, p. 238

32 Idem, p. 175.

33 Idem, p. 238 e 239.

34 DU SAULLE, Legrand. Le delire des persc'cutions. Paris: Délahaye, 1873 Apud SIGHELE, op. cit, p. 29,30 e 31.

35 SIGHELE, op. cit, p. 61.

360 trabalho é apresentado por Nina pela primeira vez em um evento: RODRIGUES, Raimundo Nina. Abasia coreiforme epidêmica no norte do Brasil. In: $3^{\circ}$ Congresso Brasileiro de Medicina e Cirurgia, Salvador, outubro de 1890. Depois, é reimpresso em duas edições de um mesmo periódico: coreiforme epidêmica no norte do Brasil. Brasil Médico, Rio de Janeiro, n. 42, 15 de novembro de 1890 e n. 43, 22 de novembro de 1890 . Finalmente ressurge na coletânea de Arthur Ramos: Abasia coreiforme epidêmica no norte do Brasil. In: As coletividades anormais. Rio de Janeiro: Civilização Brasileira, 1939. Aqui utilizamos a ultima versão, de 2006: . Abasia coreiforme epidêmica no norte do Brasil. In: As coletividades anormais. Brasília: Senado Federal, Conselho Editorial, 2006, p. 25-39.

37 Gazeta Médica da Bahia. Uma moléstia singular. Salvador, ano XIV, n. 4, out. 1882.

38 Gazeta Médica da Bahia. Choreomania. Parecer da comissão medica, nomeada pela camara municipal ácerca da moléstia que ultimamente appareceu em Itapagipe e que se tem propagado em toda a cidade. Salvador, ano XV, n. 10, p. 448, abr. 1883.

39 LEITE, Souza. Études de pathologie nerveuse. Paris: G. Steinheil Éditeur, 1889.

40 SANTANA, Antônio Samarone de et all. Dicionário biográfico de médicos de Sergipe: séculos XIX e XX. Aracaju: Academia Sergipana de Medicina, 2009; SANTOS FILHO, Lycurgo de Castro. História geral da medicina brasileira. Editora da Universidade de São Paulo, 1977.

41 "(...) imitação, resultado preparado gradualmente por uma sugestão inconsciente que foi determinada pelo espetáculo de contorcionismo de seus colegas. A representação dos gestos e dos movimentos tornou-se cada vez mais intensa e impulsiva a partir dos fatos da memória das pacientes até o dia em que foram separadas". Ver LEITE, op. cit., p. 63.

42 Ver BARATOUX, Jean Marie Joseph. Lettre écrite à M. Bourneville par le Dr Baratoux, au sujet de l'épidémie des possédées de Pledran (Bretagne). Le Progrès medical. Journal de médicine, de chirurgie et de pharmacie, Paris, $9^{\circ}$ année, $n^{0}$ 28, 9 juill., 1881.

43 CHARCOT, Jean-Martin e RICHER, Paul. su di una forma speciale d ' impotenza motrice degliorti inferiori per diffetto di coorinazioni. La Medicina contemporânea - giornale periodico mensile di Scienza pratica medico-chirurgica, n.1, 1883; Ver também BLOCQ, Paul Oscar. Sur une affection caracte 'rise'e par de l'astasie et de l'abasie. Archives de Neurologie, Paris, n. 15, p. 24-51 et 187-211, 1888.

44 LEITE, op. cit., p. 63.

45 Ibidem

46 RODRIGUES, Raimundo Nina. As coletividades anormais. Brasília: Senado Federal, Conselho Editorial, 2006, p. 61.

47 Ibidem. 
48

Ibidem.

Idem, p. 58.

Idem, p. 66.

LASĖGUE, Charles e FALRET, Jules. La folie à deux ou folie comunique. Archives générales de medicine, septembre, 1877 Apud RODRIGUES, op. cit., p. 59. Idem, 111.

Idem, 74.

Idem, p. 76.

Idem, p. 76.

Idem, p. 77.

LE BON, Gustavo. Psicologia das Multidões. Rio de Janeiro: F. Briguiet \& Cia. Editores, 1954, p. 4.

Idem, p. 19, 20, 24, 29 e 46.

RODRIGUES, op. cit., p. 62.

Idem, p. 62 e 63.

PESET, José Luis. On the History of Medical Causality. In: YES, Corinna Delkeskamp-ha e CUTTER, Mary Ann Gardell (eds.). Science, technology, and the art of medicine: European-American dialogues. Germany: Springer Science+Business Media, 1993, p. 57-74.

FOUCAULT, Michel. O nascimento da clínica. Rio de Janeiro: Forense Universitária, 2001, p. 16 e 17.

PESET, op. cit., p. 69

Idem, p. 62, 63, 64.

RODRIGUES, op. cit., p. 64.

Idem, p. 63.

Idem, p. 64.

Idem, p. 68.

0 texto aparece de inicio em um periódico brasileiro: RODRIGUES, Raimundo Nina. A loucura epidêmica de Canudos: Antônio Conselheiro e os jagunços. Revista Brasileira, Rio de Janeiro, ano III, tomo XII, fasc. 69, p. 69, 1897. Depois é publicado na França: Epidémie de folie religieuse au Brésil. Annales médico-psychologiques, Paris, mai.-jun. 1898. É, então, reimpresso na coletânea de Ramos: A loucura epidêmica de Canudos: Antonio Conselheiro e os jagunços. In: _._. As coletividades anormais. Rio de Janeiro: Civilização Brasileira, 1939. Aqui, como já foi mencionado, utilizamos a versão de 2006: _. A loucura epidêmica de Canudos: Antonio Conselheiro e os jagunços. In Editorial, 2006, p. 41-56. As coletividades anormais. Brasília: Senado Federal, Conselho

RODRIGUES, op. cit., p. 41.

Idem, p. 42.

Idem, p. 48.

Idem, p. 48.

Idem, p. 42.

MAGNAN, Valentin. Leçons Cliniques sur les Maladies Mentales. Paris: Bureaux du Progrès Mèdical/Louis Battaille, 1893 Apud ODA, Ana Maria Galdini Raimundo. Uma preciosidade da psicopatologia brasileira: A paranóia nos negros, de Raimundo Nina-Rodrigues. Revista Latinoamericana de Psicopatologia Fundamental, v. VII, n. 2, p. 151-153, 2004.

RODRIGUES, op. cit., p. 88.

Idem, p. 70.

Lente de clínica médica e importante politico do Império, foi professor e futuro sogro de Nina Rodrigues no tempo de sua graduação em medicina. Ver MAIO, Marcos Chor. A Medicina de Nina Rodrigues: Análise de uma Trajetória Científica. Cadernos de Saúde Pública, Rio de Janeiro, v. 11, n. 2, p. 226-237, abr.-jun. 1995.

9 Gazeta Médica da Bahia. Choreomania. Parecer da comissão medica, nomeada pela camara municipal ácerca da moléstia que ultimamente appareceu em Itapagipe e que se tem propagado em toda a cidade. Salvador, ano XV, n. 10, abril de 1883.

Ibidem.

Ibidem.

"É incontestável que tudo que atinge vivamente o espírito, que impressiona fortemente a imaginação, favorece singularmente, nos sujeitos predispostos, a aparição da histeria. Entre todos estes traumatismos das funções cerebrais talvez seja o ponto mais eficaz e cuja ação tenha sido mais frequentemente assinalada, que esta crença no maravilhoso, no sobrenatural, que mantém e que exagera, ou as práticas religiosas excessivas, ou uma ordem de ideias conexas, o espiritismo e sua implementação". Ver CHARCOT, Jean-Martin. Leçons sur les maladies du système nerveux. Paris, tomo III, 1887, p. 226.

3 LANNOIS, Maurice. Nosographie des chorées. Paris: Librairie J.- B. Ballière et Fils, 1886, p. 9; BLOCQ, Paul Oscar. Sur une affection caracte' rise 'e par de l'astasie et de l'abasie. Archives de Neurologie, Paris, n. 15, p. 24-51 et 187-211, 1888.

84 John Waller, historiador da medicina da Universidade do Estado de Michigan, tem um fascinante trabalho sobre a epidemia de dança que atingiu Estrasburgo, na França, em 1518. Ver WALLER, John. A time to dance a time to die. The extraordinary story of the dancing plague of 1518. London: Icon Books Ltd, 2009.

LANNOIS, op. cit., p. 11 e 12. 
RODRIGUES, op. cit., p. 36.

87 Idem, p. 37

88 Ibidem

89 LE BON, Gustavo. op. cit., p. 59.

$90 \quad$ Idem, p. 7 e 8.

91 RODRIGUES, Raimundo Nina. 0 animismo fetichista dos negros baianos. Rio de Janeiro: Fundação Biblioteca Nacional/Editora UFRJ, 2006, p. 88 e 89.

92 Idem, p. 88

930 texto foi publicado inicialmente na França: RODRIGUES, Raimundo Nina. La folie des foules. Epidémie de folie religieuse. Annales medico-psychologiques, Paris, 1901. Posteriormente foi incluído na coletânea de Arthur Ramos: A loucura das multidões. Nova contribuição ao estudo das loucuras epidêmicas no Brasil. In: _. As coletividades anormais. Rio de Janeiro: Civilização Brasileira, 1939. Aqui, utilizamos a última versão de 2006 A loucura das multidões. Nova contribuição ao estudo das loucuras epidêmicas no Brasil. In: As coletividades anormais. Brasília: Senado Federal, Conselho Editorial, 2006, p. 57-101.

94 LE BON, Gustavo. op. cit., p. 58 e 59.

95 SERGI, Giuseppe. Psicosi epidemiche. 1898 Apud RODRIGUES, op. cit., p. 83.

96 RODRIGUES, Raimundo Nina. Op. Cit., p. 84.

97 Idem, p. 80

98 Idem, p. 31

99 Idem, p. 83

100 ROM0, Anadelia. Brazil's Living Museum. Race, reform and tradition in Bahia. Chapel Hill: The University of North Carolina Press, 2010.

101 SCHWARCZ, Lilia Moritz. 0 espetáculo das raças: cientistas, instituições e questão racial no Brasil - 1870-1930. São Paulo: Companhia das Letras, 1993 Nina Rodrigues e o Direito Penal: Mestiçagem e criminalidade. In: ALMEIDA, Adroaldo J. S.; SANTOS, Lyndon de A. \& FERRETTI, Sérgio F. (orgs.). Religião, raça e identidade: colóquio do centenário da morte de Nina Rodrigues. São Paulo: Paulinas, 2007; _. Quando a Desigualdade é Diferença: Reflexões sobre Antropologia Criminal e Mestiçagem na Obra de Nina Rodrigues. Gazeta Médica da Bahia, Salvador, ano 140, n. 76, suplemento 2, 2008; Nina Rodrigues: um radical do pessimismo. In: BOTELHO, André e SCHWARCZ, Lilia Moritz (orgs.). Um enigma chamado Brasil: 29 intérpretes e um país. São Paulo: Companhia das Letras, 2009, p. 92-103.

[Recebido em Maio de 2014. Aprovado para publicação em Abril de 2015] 